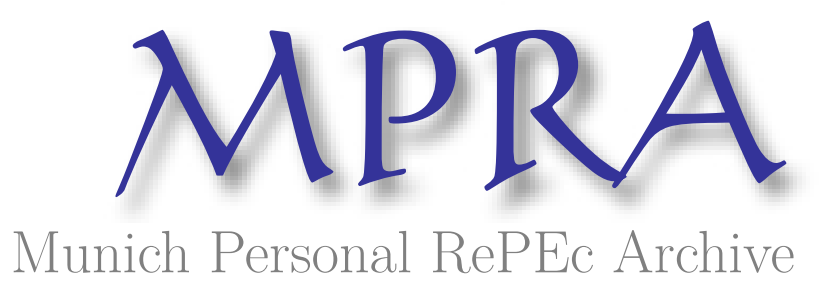

\title{
Economic Reforms and Gender-based Wage Inequality in the Presence of Factor Market Distortions
}

Chaudhuri, Sarbajit and Roychowdhury, Somasree

Dept. of Economics, University of Calcutta, India, Dept. of Economics, Lady Brabourbe College, Kolkata, India

4 March 2014

Online at https://mpra.ub.uni-muenchen.de/54111/

MPRA Paper No. 54111, posted 05 Mar 2014 01:33 UTC 


\title{
Economic Reforms and Gender-based Wage Inequality in the Presence of Factor Market Distortions
}

\author{
Sarbajit Chaudhuri, Dept. of Economics, University of Calcutta, India \\ and
}

Somasree Roychowdhury, Dept. of Economics, Lady Brabourne College, Kolkata, India

Address for communication: Sarbajit Chaudhuri, 384/1, M.B. Road, Nimta, Belgharia, Kolkata 700049, India. Tel: 91-9830530963 (M), 91-33-2557-5082 (C.U.). Fax: 91-33-2844-1490 (P). Email: sarbajitch@yahoo.com

(This version: March 04, 2014)

\begin{abstract}
A simple three-sector general equilibrium model has been developed with both male and female labour and factor market distortions. The effects of different liberalized economic policies have been examined on the gender-based wage inequality. The analysis finds that credit market reform and tariff reform produce favourable effects on the wage inequality while the liberalized investment policy becomes counterproductive. These results have important policy implications for a small open developing economy.
\end{abstract}

Keywords: Male labour, female labour, gender wage inequality, labour market distortion, credit market distortion, economic reforms, general equilibrium.

JEL classifications: D50, J16, F21. 


\section{Economic Reforms and Gender-based Wage Inequality in the Presence of Factor Market Distortions}

\section{Introduction}

Gender empowerment impacts the quality and efficiency of decision making and resource allocation, which is relevant for social and economic development. Gender inequality, in terms of access to education, health facilities and credit is a predominant feature of most developing countries. Women also face gender discrimination in the labour market and financial market, limiting the economic progress of countries. The discrimination in the labour market between men and women can be observed in all countries, although it is much more pronounced in the developing countries.

While the manifestations of gender discrimination are multi-dimensional and intertwined, an overreaching phenomenon is gender wage inequality. Gender wage discrimination not only, by itself, represents an inequality, but also is a reason of many other types of gender inequalities. Low wages for women leads to economic dependence and thereby their lower social status and decision making position in society. The reason(s) for gender wage gap is a very contentious issue and various schools of thought have endeavored to ascribe reasons for the same. The neoclassical view is that free markets, through the competition process, ensure that wage differentials are eliminated. The cultural historians are of the view that gender wage differentials are because of cultural/societal stereotyping of women's work for low-end, less remunerated jobs. Such culture-driven occupational segregation persists even under competitive conditions. Joyce Burnette ( 2008) has, however, through her studies on gender work and wages in Industrial Revolution Britain, concluded that occupational segregation was not the cause of wage gap but a way to shelter women from "the full force of their lower productivity" caused by their less physical strength and child care responsibilities. Another school of thought, championed by Jane Humphries (2009), propounded that powerful elements in society manipulate the various factors of production to further their wealth and status, which manifests in inequalities, including gender wage inequality. 
The size of the gender wage gap varies across countries as well as within the country. In many countries of Asia, Middle East and North Africa, the gap is upwards of $40 \%$ in some sectors (Corley, Perardel and Popova 2005). In Latin America and the Caribbean, most women earn on an average $69 \%$ of men's income. In the context of India, gender wage gap at the National level, on an average, for female labour is $70 \%$ of that of daily male wage rate in the agricultural sector in India (National Sample Survey, 2004). Chaudhuri \& Panigrahi (2013) have highlighted the findings of the ASI - 2009-10 survey, wherein the All India Average Wage per day for female workers was Rs 147/- as against Rs 303/- for male workers

The developing countries have chosen free trade as their development strategy and been vigorously implementing various liberalized economic policies over the last three decades. The ongoing process of globalization must have produced a significant impact on the gender-based wage inequality. These policies change the relative factor prices and lead to reallocation of factors of production among sectors that use them with different intensities and thereby change their employment and wages. Therefore liberalization policies affect the choice of employment between men and women workers and their respective remunerations (UNCTAD 1999).

Several empirical studies have tried to find out the impact of trade openness to gender wage inequality although their findings of the consequences on the inequality have been mixed in nature. For example, Berik 2000, Fontana and Wood 2000: Oosetendorp 2009 Dell (2005), Artecona \& Cunningham (2002), Garcia-Cuellar (2001) have shown that increased volume of trade due to openness has decreased the gender wage inequality. It has been effectively proved by the various studies that economic integration of Mexico in NAFTA since 1994 has caused the expansion of female levels of participation, erosion of the gender gap and increased volume of trade. On the other hand, there are several other studies like Artecona \& Cunningham (2001), Menon and Rodgers (2006), Dutta Gupta (2002), Fontana (2002), Berik, Rodgers, and Zveglich (2004) which show that trade openness has increased the gender wage inequality.

Studies like Menon and Rodger (2009), Chamargwala (2006), Bhattacharya and Rahaman (1999) have concentrated on the impact of different liberalization policies, such as tariff reduction, 
deregulation of licensing, etc in developing countries like India, Pakistan Bangladesh and South Asian economies. These studies concluded that trade liberalization widened the gender pay gap. It was found that women are generally more constrained than men from reaping the benefits from the expansion of trade in agriculture.

Most of the work done on gender wage gap and economic liberalization are empirical in nature. However, there should be a theoretical literature that can be useful in analyzing the consequences of different liberalized economic and other policies on the gender wage inequality in a simple general equilibrium structure and be useful in prescribing policy measures based on the theoretical findings that can be useful for mitigating the gravity of the problem. The theoretical literature in this area has not emerged as yet. However, mention should be made of a paper by Mukhopadhyay and Chaudhuri (2013) (MC (2013) hereafter) which has examined the consequences of trade reform and inflow of foreign capital on gender wage inequality and welfare of the economy.

The present work is different from that of MC (2013) in a number of ways. First, in MC (2013) any convincing explanation as to why the gender wage gap arises has not been provided. Here we have tried to offer quite a few of such explanations in terms of differences in calorie intakes, spending patterns and physiological factors ${ }^{1}$ between men and women. Second, while MC (2013) considered a competitive male labour market we have considered a formal-informal segmentation of the male labour market which is closer to reality especially in the context of a developing economy. ${ }^{2}$ Third, we allow capital mobility between the female labour oriented export sector (sector 2) and the formal import-competing sector (sector 3) whereas in MC (2013) capital mobility is allowed only between the two informal sectors. Fourth, the present work

\footnotetext{
1 According to Gustafsson and Lindenfors (2004) most males are stronger than females. See also http://en.wikipedia.org/wiki/Sex_differences_in_humans in this context.

2 The female labour market in a developing country is also segmented. However, we have excluded female labour in the formal manufacturing sector (sector 3) of the economy owing to the empirical fact that only a very small proportion of the aggregate female labour force is employed in that sector. See also footnotes 4 and 5 .
} 
examines the role of the capital market imperfection, which is a salient feature of the developing country like that of ours, in explaining the gender wage differential which is not dealt in MC (2013). Finally, our results are more distinct and free of parametric restrictions that lead to stronger policy implications than their work.

\section{The Model}

We develop a simple three-sector, full-employment general equilibrium model for a small open developing economy with four inputs. The four inputs of production are male labour $(M)$, female labour $(F)$, land $(N)$ and capital $(K)$. Here capital means working capital.

Sector 1 is an informal sector that produces an exportable agricultural commodity, $X_{1}$ (say food), using male labour, female labour and land. Sector 2 is a female labour-oriented informal sector that produces also an export good, $X_{2}$ by means of female labour and capital. A classic example of such a sector, in the developing countries, would be the booming garment industry in Bangladesh, which is both female worker and export oriented (Kornick 2005). A few other such industries are: tea, tobacco and food-processing. ${ }^{3}$ Sector 3 is organized formal sector that produces a manufacturing good, $X_{3}$, (e.g. machinery and equipment, transport equipment, basic metals, fabricated metal products etc.) with the help of male labour and capital. This is the tariffprotected import-competing sector of the economy. We exclude female labour in the production of commodity 3 primarily because the percentage of female labour used in the production activities mentioned above is insignificant (see Chaudhuri and Panigrahi (2013), Table 2). ${ }^{\mathbf{4} 5}$

\footnotetext{
${ }^{3}$ See Mukhopadhyay and Chaudhuri (2013), footnote 8 in this context.

${ }^{4}$ See also Selected Socio-Economic Statistics, India 2011 in this context.

5 It may intuitively be checked that the qualitative results of the model get through even if one includes female labour in sector 3 . The algebra of the model would, however, be a bit more complicated.
} 
Male workers in the agricultural sector (sector 1) earn the competitive wage, $W_{M}$, while the male wage rate in the manufacturing sector (sector 3) is $W_{M}^{*}$, which is institutionally determined, and $W_{M}^{*}>W_{M}$. The male labour allocation mechanism is as follows. Male workers first compete for getting jobs in sector 3 where the wage rate is high due to institutional reasons. But those who cannot get employment in that sector are automatically absorbed in sector 1 providing the competitive and low wage. So we have distortions in the male labour market. The female labour market is, however, perfect. Land is specific to sector 1. Capital flows freely between sector 2 and sector 3 although the former sector faces a higher cost of capital vis-à-vis the latter. Owing to the assumption of a small open economy, commodity prices are internationally given. The endowments of the four primary inputs in the economy are $M, F, K$ and $N$, respectively. All the factors of production are fully employed. Production functions in all the sectors exhibit constant returns to scale with diminishing marginal productivity to each factor.

The ICMR (2010, Table 4.1) report has pointed out that the minimum calorie requirement of a male worker to maintain the same level of productivity or efficiency is higher than that of a female worker. Furthermore, the spending patterns of the male and female workers are significantly different. Women are more likely than men to spend a significantly higher proportion of their income on purchases of goods and services that promote the nutrition, health and general well being of their families (Duncan 1997; Quisumbing et al. 1998; Kurz and Welch 2000). Men tend to spend most of their income on non-food items and their personal luxury articles like alcohol and cigarettes or reinvest it in their work or businesses (Guyer 1988; Hoddinott and Haddad 1995; Anderson and Baland 2002).

The physical efficiency of male labour is greater than that of female labour. ${ }^{6}$ This difference may arise due to biological difference or the difference in calorie intakes and the resulting nutritional difference between the two types of labour. Indian women are traditionally more concerned

\footnotetext{
6 This is analogous to the productivity difference between adult labour and child labour. In the literature on child labour the productivity of adult labour has been considered to be significantly greater than that of child labour although in different informal sectors these two types of labour are substitutes. The difference in labour productivities results in their wage differential. See for example, Basu and Van (1998), Chaudhuri and Dwibedi (2006, 2007, 2010) etc.
} 
about the well-being and nutritional status of their husbands and children relative to those of their own. This may be one of the main reasons why malnutrition is much pronounced among women, especially in the rural areas of the developing economies including India.

If we keep all these in mind it is not unreasonable to assume that in a largely male-dominated working household the male and female workers consume exactly those amounts of food (commodity 1 in the present model) just sufficient enough to maintain their existing physical productivities. ${ }^{7}$ The family income in excess of that amount is largely spent on non-food items and luxury goods of the male worker that do not contribute to their productivities.

In mathematical terms, the efficiency of a male worker, denoted $h_{m}$, is given by $h_{m}=h\left(\overline{\mathrm{c}}_{m}\right)$ with $h^{\prime}()>0,. h^{\prime \prime}()<$.

where $\bar{c}_{m}=$ (minimum) amount of calorie intake by a male labour.

Similarly, the efficiency of a female labour, $h_{F}$, is

$$
h_{f}=h\left(\bar{c}_{f}\right) \text { with } h^{\prime}(.)>0, h^{\prime \prime}(.)<0
$$

where $\bar{c}_{f}=($ minimum $)$ amount of calorie intake by a female labour.

Clearly, $h_{m}>h_{f}$ as $\bar{c}_{m}>\bar{c}_{f}$. As commodity prices are internationally given by the small open economy assumption, the amounts of expenditures required for $\bar{c}_{m}$ and $\bar{c}_{f}$ calorie intakes are also given. This can possibly explain the disparities between male wage and female wage. ${ }^{\mathbf{8}, 9}$

7 This may not be the case of male workers employed in sector 3 where they receive a high unionized wage which is greater than the competitive male wage in sector 1 . If male workers in sector 3 consume more calories than, $\bar{c}_{m}$, level the productivity of each of them is likely to be higher than their counterparts in sector 1. However, for simplifying matters and keeping our analysis focused on the gender wage inequality the possibility of such a productivity differential is assumed away.

${ }^{8}$ We may recall the literature on child labour in this context. See also footnote 6 .

9 In this connection it is important to mention that Kornick (2005) has demonstrated in his study that women labour is predominantly employed in the unorganized sector. The 68th Round of National Sample 
So, we can write $W_{M}>W_{F}$ where $W_{M}$ is wage for male labor, and $W_{F}$ is wage for female labour.

It is extremely important to mention that although the gender wage gap exists the absolute wages and the magnitude of the wage gap in our model are determined by competitive forces. ${ }^{\mathbf{1 0}}$

The general equilibrium structure of the model is represented by the following set of equations.

$$
\begin{aligned}
& W_{M} a_{M 1}+W_{F} a_{F 1}+R a_{N 1}=1 \\
& W_{F} a_{F 2}+r_{1} a_{K 2}=P_{2} \\
& W_{M}^{*} a_{M 3}+r_{2} a_{K 3}=P_{3}(1+t)=P_{3}^{*}
\end{aligned}
$$

Equations (3) - (5) are the three competitive industry equilibrium conditions.

Here, $a_{j i}$ is the amount of the $j$ th factor required to produce 1 unit of output of the $i$ sector with $j=M, F, L, K$ and $i=1,2,3 ; P_{i}=$ the internationally given price of the $i$ th commodity with $i=2,3 . t$ is the ad-valorem rate of tariff on sector 3. The other symbols have already been defined. Finally, commodity 1 is taken to be the numeraire.

We have assumed capital market imperfection in the economy. ${ }^{\mathbf{1 1}}$ The cost of capital in sector 2 is higher than that in sector 3. The relationship between the two interest rates is given as follows.

Survey (2011-12) has found that women are mainly engaged in rural areas as cultivators and agricultural labourers and in urban areas, fourth-fifth of the working women are involved in unorganized sectors such as household industries, petty trade and services, building and construction. Women make up just a fifth of the organized sector workforce. Since the proportion of women working in unorganized sector is high, the overall average daily wage rate of women labour gets depressed.

${ }^{10}$ Due to existence of imperfections in the market for male labour in the organized sector (sector 3 ) the male workers receive the unionized wage which is institutionally determined while their counterparts in the agricultural sector (sector 1) receive a low competitive wage. For a theory of determination of the unionized wage in the formal sector one may go through Chaudhuri (2003) and Chaudhuri and Mukhopadhyay (2009) among others.

11 We also consider capital market imperfections in our model. The informal sector firms being unregistered in nature have very little access to the organized credit market. They borrow a lion's share of their working capital from the informal sector lenders. On the other hand, these exploitative lenders due to their easy access to the formal capital market add on, largely, unregulated margins for re-lending to the 
$r_{1}=\beta r_{2}$

Here, $\beta$ is a parameter which is determined by institutional characteristics of the credit market and $\beta>1$ implies capital market imperfections. ${ }^{12}$ It is easily seen that $r_{1}>r_{2}$ if $\beta>1$.

Complete utilization of different factors of production can be expressed by the following equations.

$$
\begin{aligned}
& a_{N 1} X_{1}=\bar{N} \\
& a_{M 1} X_{1}+a_{M 3} X_{3}=M h_{m}\left(\bar{c}_{m}\right) \\
& a_{F 1} X_{1}+a_{F 2} X_{2}=F h_{f}\left(\bar{c}_{f}\right) \\
& a_{K 2} X_{2}+a_{K 3} X_{3}=\left(\bar{K}_{D}+K_{F}\right)=K
\end{aligned}
$$

where $X_{i}=$ output level of $i$ th sector for $i=1,2,3 ; M=$ male population; $M h_{m}=$ male population in terms of efficiency unit. $F=$ female population; $F h_{f}=$ female population in terms of efficiency unit. $\bar{K}_{D}=$ amount of domestic capital; $K_{F}=$ amount of foreign capital; $K=$ aggregate capital endowment of the economy which is $\left(\bar{K}_{D}+K_{F}\right) ; N=$ given land endowment of the economy. Domestic capital and foreign capital are perfect substitutes to each other.

From equation (7) we can write

$$
X_{1}=\frac{\bar{N}}{a_{N 1}}
$$

informal sector borrowers. This raises the cost of financing of the unorganized sector. These characteristics of the informal credit market have been adequately described and analyzed in Bhaduri (1977), Rudra (1982), Basu (1984, 1997), Basu and Bell (1991), Mishra (1994), Chaudhuri (2003) and Chaudhuri and Mukhopadhyay (2009). For a theory of determination of the informal interest rate in a general equilibrium structure, beginning from the microeconomic behaviour of the informal sector lender in an imperfectly competitive credit market, one may go through Chaudhuri and Gupta (2014).

12 See Chaudhuri (2003) and Chaudhuri and Mukhopadhyay (2009) in this context. 
Substituting this value of $X_{1}$ in equation (8) and solving we get

$$
X_{3}=\left(\frac{1}{a_{M 3}}\right)\left(h_{m} M-\frac{a_{M 1}}{a_{N 1}} \bar{N}\right)
$$

Similarly substituting the value of $X_{1}$ in equation (9) and solving we get

$$
X_{2}=\left(\frac{1}{a_{F 2}}\right)\left(h_{f} F-\frac{a_{F 1}}{a_{N 1}} \bar{N}\right)
$$

There are eight endogenous variables in the system: $W_{M}, W_{F}, R, r_{1}, r_{2}, X_{1}, X_{2}$, and $X_{3}$ and exactly the same number of independent equations, (3) - (10). This is an indecomposable production structure. Some of the factor prices depend on both commodity prices and factor endowments. Therefore, any changes in the factor endowments will affect some of the factor prices, which in turn affect the factor-coefficients. The policy parameters of the system are $\beta, t$ and $K$.

The endogenous variables are determined as follows. $r_{2}$ is determined from equation (5) as $W_{M}^{*}$ is exogenously given. Once $r_{2}$ is obtained $r_{1}$ is solved from equation (6). Then $W_{F}$ is determined from equation (4). So, these three depend only on commodity prices. Then, using equations (8.1), (9.1) and (10) we can find

$$
\left(\frac{a_{K 2}}{a_{F 2}}\right)\left(h_{f} F-\frac{a_{F 1}}{a_{N 1}} \bar{N}\right)+\left(\frac{a_{K 3}}{a_{M 3}}\right)\left(h_{m} M-\frac{a_{M 1}}{a_{N 1}} \bar{N}\right)=K
$$

$W_{M}$ and $R$ are obtained by solving equation (3) and equation (10.1) simultaneously. Once factor prices are determined, factor coefficients are also obtained. From equation (7) we can determine the value of $X_{1}$. Finally, from equations (8.1) and (9.1), $X_{3}$ and $X_{2}$ are determined, respectively.

The average male wage is denoted by $W_{M}^{a}$ where

$W_{M}^{a}=\lambda_{M 1} W_{M}+\lambda_{M 3} W_{M}^{*}$ 
where, $\left(\lambda_{M 1}+\lambda_{M 3}\right)=1$

So, $W_{M}^{a}=W_{M}^{*}-\lambda_{M 1}\left(W_{M}^{*}-W_{M}\right)$

The absolute gender wage gap is $\left(W_{M}^{a}-W_{F}\right)$ implying that the average male wage rate is greater than the female wage rate. The relative gender wage inequality, denoted $I$, is given by

$I=\left(\hat{W}_{M}^{a}-\hat{W}_{F}\right)$

Here '^' implies proportional change e.g. $\hat{W}_{F}=\left(\frac{d W_{F}}{W_{F}}\right)$.

The relative gender wage inequality worsens due to any policy changes if $\left(\hat{W}_{M}^{a}-\hat{W}_{F}\right)>0$ i.e. $I>0$ while it improves if $\left(\hat{W}_{M}^{a}-\hat{W}_{F}\right)<0$ i.e. $I<0$.

\section{Comparative statics}

In this section of the paper we attempt to find out the effects of credit market reform, trade reform, and an inflow of foreign capital on the gender wage inequality in the existing set-up. A credit market reform is captured through a reduction in $\beta$. A trade reform can be encapsulated through a reduction in the ad-valorem tariff rate, $t$. Finally, a policy of investment liberalization in this model means an increase in the endowment of the foreign capital in the economy i.e. $K_{F}$.

Differentiating equation (5) we obtain

$\hat{r}_{2}=\frac{T \hat{t}}{\theta_{K 3}}$

Then totally differentiating equation (6) and using (13) one finds

$\hat{r}_{1}=\hat{\beta}+\frac{T \hat{t}}{\theta_{K 3}}$

Differentiating equation (4), using (14) and simplifying we find 
$\hat{W}_{F}=-\frac{\theta_{K 3}}{\theta_{F 2}} \hat{\beta}-\frac{T \hat{t}}{\theta_{F 2}}$

Totally differentiating equation (11.1) we find

$\hat{W}_{M}^{a}=\left(\frac{W_{M} \lambda_{M 1}}{W_{M}^{a}}\right)\left[\hat{W}_{M}-\left(W_{M}^{*}-W_{M}\right) \hat{\lambda}_{M 1}\right]=\left(\frac{W_{M} \lambda_{M 1}}{W_{M}^{a}}\right)\left[\hat{W}_{M}-\left(W_{M}^{*}-W_{M}\right)\left(\hat{a}_{M 1}+\hat{X}_{1}\right)\right]$

Using equations (15) and (16) from (12) we finally find that

$I=\left[\left(\frac{W_{M} \lambda_{M 1}}{W_{M}^{a}}\right)\left[\hat{W}_{M}-\left(W_{M}^{*}-W_{M}\right)\left(\hat{a}_{M 1}+\hat{X}_{1}\right)\right]-\hat{W}_{F}\right]$

Here $\theta_{j i}$ and $\lambda_{j i}$ respectively denote the distributive and allocative shares of the ${ }^{j}$ th input in the ${ }^{i}$ th sector for $j=M, F, N, K$ and $i=1,2,3$.

Using equations (15) - (17) the following propositions can easily be established.

Proposition 1: A policy of credit market reform unambiguously improves the gender wage inequality.

Proposition 2: Trade reform in the form of a reduction in the rate of import tariff unequivocally lowers the gender-based wage inequality.

Let us now explain these results in economic terms. A policy of credit market reform, captured through a reduction in the degree of credit market imperfection $(\beta)$ lowers the power of the exploitative informal sector lenders and hence their ability to mark up interest rate over the competitive rate $\left(r_{2}\right)$. So, the informal interest rate $\left(r_{1}\right)$ falls (equation 6) although $r_{2}$ does not change. Then from the zero-profit condition for sector 2 (equation 4) it follows that the female wage $\left(W_{F}\right)$, rises. Sector 2 expands as the effective price of its product net of capital cost has increased. However, producers in this sector would substitute female labour by capital as the latter input has become relatively cheaper. The expanding sector 2 requires more capital which must come from sector 3 (note that all factors are fully utilized). Sector 3 contracts both in terms of output and employment of male labour for want of capital. Male workers who have lost their 
jobs in the formal sector that pays a higher unionized wage $\left(W_{M}^{*}\right)$ now move to sector 1 depressing the competitive male wage $\left(W_{M}\right)$. As sector 1 now absorbs more male labour than before, the proportion of male employment to total male endowment i.e. $\lambda_{M 1}$ rises. Quite naturally the average male wage $\left(W_{M}^{a}\right)$ falls. As the female wage $\left(W_{F}\right)$ has already risen the male-female wage inequality improves (falls).

On the other hand, a policy of trade reform lowers the ad-valorem rate of tariff $(t)$ on the import of commodity 3 that lowers the domestic price of that commodity i.e. $P_{3}(1+t)$. The competitive return to capital $\left(r_{2}\right)$ falls as the unionized male wage $\left(W_{M}^{*}\right)$ is given (equation 5). This lowers the interest rate in sector 2 (see equation 6). This leads to an increase in the female wage rate $\left(W_{F}\right)$ (equation 4). As $P_{3}(1+t)$ has decreased sector 3 contracts both in terms of output and employment of male labour ; thereby, releasing capital to sector 2 and male labour to sector 1. This depresses the competitive male wage in sector $1\left(W_{M}\right)$. More male labour are now employed in the lower wage-paying sector (note that $W_{M}^{*}>W_{M}$ ). This means that $\lambda_{M 1}$ rises. Quite naturally, the average male wage $\left(W_{M}^{a}\right)$ plummets. The gender wage inequality improves as the female wage $\left(W_{F}\right)$ has already increased.

Finally, we would like to analyze the consequence of the liberalized investment policy on the gender-based wage inequality. The liberalized investment policy in the present context implies an inflow of foreign capital inflow. If there occurs an inflow of foreign capital, the foreign capital stock of the economy $\left(K_{F}\right)$ goes up. Both sector 2 and sector 3 expand as they use capital. Sector 3 now demands more male labour which comes from sector 1 while the demand for female labour rises in sector 2 which is met by release of female labour by sector 1 . Consequently, the competitive male wage $\left(W_{M}\right)$ increases because its demand in the economy has increased and $W_{M}$ depends on both factor endowments and commodity prices. Although the demand for female labour has also increased the female wage $\left(W_{F}\right)$ cannot rise as it is 
determined from the zero-profit condition of sector 2 (equation 4 ). Note that $r_{2}, r_{1}$ and $W_{F}$ are determined from equations (5), (6) and (4), respectively. So, we find that the competitive male wage $\left(W_{M}\right)$ and the proportion of male labour employed in the higher wage-paying sector have increased leading to an increase in the average male wage in the economy $\left(W_{M}^{a}\right)$. The genderbased inequality unambiguously deteriorates (rises). This leads to the final proposition of the model.

Proposition 3: The liberalized investment policy in the form of inflows of foreign capital unambiguously worsens the male-female wage inequality.

\section{Concluding remarks and policy implications}

The gender-based wage inequality in the labour market is a persistent problem across countries, especially the developing ones. The developing economies have been vigorously implementing the liberalized economic policies over the last three decades which must have important consequences on the problem. We have developed a simple three-sector general equilibrium model with both male and female labour and factor and commodity market distortions with a view to examine the impacts of liberalization drives by the developing nations on the gender wage inequality. We have found that policies of credit market reform and tariff reform produce favourable effects on the inequality while the liberalized investment policy becomes counterproductive. The policy recommendations that readily follow from the results are to go for credit market and trade reforms vigorously. But, the policymakers should be careful in implementing the investment reform as it is likely to backfire unless the policy is accompanied by credit market reformatory policies like curbing the power of the exploitative informal lenders by allowing small firms in the informal sector to borrow their working capital from the organized credit market at the competitive rate. This would help these firms to grow and their demand for female labour to pick up significantly. Consequently, the female wage rises that lowers the gender wage inequality. If these supplementary policies are undertaken the liberalized investment policy would not only lead to a balanced growth of the economy but also definitely improve the gravity of the inequality problem. 
Finally, it should be mentioned that in the present work we have analyzed the possible outcomes of different liberalized economic policies on the male-female wage inequality in the simplest possible manner. Some of the assumptions like exclusion of female labour in the formal sector of the economy and classification of both types of labour according to their skills and absence of non-traded goods are restrictive. Furthermore, the determination of the supply of each type of labour from the maximizing behaviour of a working household could be an interesting exercise. Our future research should address these aspects.

\section{References:}

Anderson, S. and Baland, J. M. (2002): 'The economics of Roscas and intra-household resource allocation', The Quarterly Journal of Economics 117(3), 963-995.

Artecona, R. and Cunningham ,W (2002): 'Effects of trade liberalization on the gender wage gap in Mexico', Gender and Development working paper series 21 The World Bank Development Group.

Basu, K. and Van, P. H. (1998): 'The economics of child labour', American Economic Review, $88(3), 412-427$.

Basu, K. and Bell, C. (1991): 'Fragmented duopoly: theory and applications to backward agriculture', Journal of Development Economics 36, 259-81.

Berik, G., van der Meulen Rodgers, Y. and Zveglich, J. E,( 2002): 'Does trade promote gender wage equity? Evidence from East Asia' CEPA Working paper 2002-14 New York: New School University

Berik, G., Rodgers, Y. and Zveglich, J. (2004): 'International trade and gender wage discrimination: evidence from East Asia', Review of Development Economics, 8(2), 237-254.

Berik, G.( 2000): 'Mature export-led growth and gender wage inequality in Taiwan'. Feminist Economics 6(3), 1-26.

Bhaduri, A. (1977): 'On the formation of usurious interest rates in backward agriculture,' Cambridge Journal of Economics1 4, 341-352. 
Bhattacharya, D. and Mustafizur R. (1999): Female employment under export propelled industrialization: Prospects for internalizing global opportunities in the apparel sector in Bangladesh, Occasional Paper no. 10, (UNRISD), Geneva.

Burnette .J. (2008): 'Gender, work and wages in industrial revolution Britain' Cambridge: Cambridge University Press, Cambridge.

Chamarbagwala, R.( 2006):. Economic liberalization and wage inequality in India. World Development 34, no. 12: 1997-2015

Chaudhuri, S. (2003): 'How and how far to liberalize a developing country with informal sector and factor market distortions', Journal of International Trade and Economic Development, 12(4), 403-428.

Chaudhuri, S. and Mukhopadhyay, U. (2009): Revisiting the Informal Sector: A General Equilibrium Approach. Springer: New York.

Chaudhuri, S. and Gupta, M. R. (2014): 'International factor mobility, informal interest rate and capital market imperfection: a general equilibrium analysis', Economic Modelling 37(C), 184182.

Chaudhuri, S. and Dwibedi, J. K. (2007): 'Foreign capital inflow, fiscal policies and the incidence of child labour in a developing economy', The Manchester School 75(1), 17-46.

Chaudhuri,S \& Dwibedi, J.K (2006): 'Trade liberalization in agriculture in developed nations and incidence of child labour in a developing economy,' Bulletin of Economic Research 58(2), 129-150.

Chaudhuri, B. and Panigrahi.A. K. (2013): 'Gender bias in Indian industry'; The Journal of Industrial Statistics 2(1) 108-127.

Corley, M., Perardel, Y. and Popova, K. (2005): 'Wage inequality by gender and occupation: a cross-country analysis’, Employment Strategy Papers No. 20, International Labour Office.

Datta Gupta, N. (2002): 'Gender, pay and development: a cross-country analysis,' MPRA Paper 15311, University Library of Munich, Germany. 
Dell, M. (2005): 'Widening the border: The impact of Nafta on female labor force participation in Mexico', Oxford University

Duncan, T. (1997): 'Incomes, expenditures and health outcomes: Evidence on intrahousehold resource allocation', in Haddad, L., Hoddinott, J. and Alderman, H. (eds.), Intrahousehold Resource Allocation in Developing Countries: Models, Methods and Policy, Baltimore and London: The Johns Hopkins University Press.

Dwibedi, J. K. and Chaudhuri, S. (2010): 'Foreign capital, return to education and child labour', International Review of Economics and Finance, 19(2), 278-286.

Enriqueta Camps, Maria Camou, Silvana Maubrigades and Natalia Mora-Sitja,(2006): 'Globalization and wage inequality in South And East Asia and Latin America : A gender approach'; Barcelona Economics Working Paper Series Working Paper nº 284 July 2006

Fontana, M. (2002): 'Modelling the effect of trade on women at work and at home: A comparative perspective'. Paper presented at SIAP Workshop, 7-8 November, in Brussels, Belgium. http://www.cepii.fr/anglaisgraph/communications/pdf/2002/siap1102/fontana.pdf

Fontana, M., and A. Wood( 2000): 'Modelling the effects of trade on women, at work and at home'; World Development 28(7), 1173-90.

Garcia Cuellar, R (2001): 'Essays on the effects of trade and location on the gender gap: A study of the Mexican labor market'; Harvard University, Economics Department, Doctoral Dissertation working Paper.

Government of India. (2000): Report of the second national commission on labour, NSSO.

Gustafsson A and Lindenfors P (2004): 'Human size evolution: no allometric relationship between male and female stature'; Journal of Human Evolution 47 (4): 253266. doi:10.1016/j.jhevol.2004.07.004. PMID 15454336

Guyer, J. (1988): 'Dynamic approaches to domestic budgeting: Cases and methods from Africa', in Dwyer, D. and Bruce, J. (eds.), A Home Divided: Women and Income in the Third World, Stanford. 
Hazarika, G., and R. Otero, (2004): 'Foreign trade and the gender earnings differential in urban Mexico'. Journal of Economic Integration 19, no. 2: 353-73.

Hoddinott, J., and L. Haddad, (1995): Does female income share influence household expenditure? Evidence from Cote d'Ivoire. Oxford Bulletin of Economics and Statistics LVII: 77-97.

Humphries .J,(2009) : 'The gender gap in wages: Productivity or prejudice or market power in pursuit of profits'; Social Science History volume 33, number 4, winter2009, pp 481-488

Indian council of medical research (2010,Table 4.1)

Korinek (2005): 'Trade and Gender: Issues and Interactions' in the OEDC Working Paper

Kurz, K. M. and Welch, C. J. (2000): Enhancing nutrition results: The case for a women's resources approach, Washington, DC: International Center for Research on Women.

Menon, N., and Y. Rodgers, ( 2009): 'International trade and the gender wage gap: New evidence from India's manufacturing sector'. World Development 37(5), 965-81.

Mishra, A. (1994): 'Clientelization and fragmentation in backward agriculture: forward induction and entry deterrence', Journal of Development Economics, 45, 271-85.

Mukhopadhyay and Chaudhuri (2012): 'Economic liberalization, gender wage inequality and welfare'; Journal of International Trade and Economic Development 22(8), 1214-1239.

National Sample Survey (2011-12): Government of India.

Oostendorp, R. (2004): 'Globalization and the gender wage gap', World Bank Policy Research Working Paper 3256

Oostendorp, R. (2009): 'Globalization and the gender wage gap'; World Bank Economic Review 23, no. 1: 141-61.

Quisumbing, A. R., Haddad, L., Meinzen-Dick, R. and Brown, L. R. (1998): 'Gender issues for food security in developing countries: Implications for project design and implementation', Canadian Journal of Development Studies, XIX, Special Issue, 185-208. 
Reilly, B., and Dutta P.V, (2005): 'The gender pay gap and trade liberalization: evidence for India', PRUS Working Paper no. 32, University of Sussex, UK

Rudra, A (1982): Indian Agricultural Economics: Myths and Realities. Allied Publishers, New Delhi.

UNCTAD (1999): World Investment Report. New York, United Nations. 